\title{
SCOPE OF FRAUDULENT CONVEYANCES AND FRAUDULENT PREFERENCES LEGISLATION IN ALBERTA
}

\author{
NIGEL J. HOWCROFT*
}

\begin{abstract}
The specific legislation in Alberta dealing with fraudulent preferences and conveyances is discussed. The Fraudulent Preferences Act, the Bankruptcy Act, the Statute of Elizabeth and the Criminal Code all contain relevant provisions. The author examines the operation and scope of this legislation and draws conclusions as to how a solicitor may advise a client regarding the legality of a proposed transfer of assets.
\end{abstract}

\section{INTRODUCTION}

One consequence of economic recession is increased frequency of insolvency among corporations and individuals. During and following such a period, the possibility of attracting the sanctions of fraudulent conveyances and fraudulent preferences legislation looms larger and must be considered more seriously in relation to decisions taken in the management of business affairs. The purpose of this paper is to examine the scope of fraudulent conveyances and fraudulent preferences legislation in force in Alberta and to discuss judicial application of the legislation. In particular, the meanings of "fraudulent intent", of "creditor" and of "creditor and others" for the purposes of the legislation using those terms will be reviewed. As well, the relevance of consideration given in exchange for assets transferred by a debtor will be considered. It will be shown that, in most respects, the sweep of fraudulent conveyances and fraudulent preferences is comprehensive indeed, but that there are practical and evidentiary barriers which mitigate the effect and utility of the legislation.

\section{THE LEGISLATION}

\section{A. THE FRAUDULENT PREFERENCES ACT'}

The Fraudulent Preferences Act applies to a broad range of transactions enumerated as follows: ${ }^{2}$

every gift, conveyance, assignment, transfer, delivery over or payment of goods, chattels or effects or of bills, bonds, notes or securities or of shares, dividends, premiums or bonus in any bank, company or corporation, or of any other property, real or personal....

Assuming that the intention requirements (discussed below) can be proven, such a transaction may be challenged if it is made for insufficient consideration and "by a person at a time when he is in insolvent circumstances or is unable to pay his debts in full or knows that he is on the

* Barrister and solicitor with the firm of Cormie Kennedy in Edmonton. The writer gratefully acknowledges the assistance of E.S. Cook, J.A. Cross and D.W. Scott, all of whom reviewed earlier drafts of the paper and provided useful comments.

1. R.S.A. 1980, c. F-18. The legislation has been determined to be intra vires of the Province: Anderson Lumber Company Ltd. v. Canadian Conifer Lid. (1977) 25 C.B.R. (N.S.) 35 (Alta. C.A.); Canadian Imperial Bank of Commerce v. Grande Cache Motor Inn Ltd. (1978) 4 Alta. L.R. (2d) 319 (S.C.).

2. Ss. 1,2 and 3. Even though the Act is expressed to apply to any property, "real or personal", one case indicates that the Act applies only to personal property: Re Sauer and Sauer (1981) 128 D.L.R. (3d) 523 (Q.B.). 
eve of insolvency" ${ }^{3}$ If the transaction is made "with intent to defeat, hinder, delay or prejudice his creditors or any one or more of them" "it is a fraudulent conveyance. If it is made "to or for a creditor with intent to give that creditor preference over the other creditors of the debtor or over any one or more of them"'s it is a fraudulent preference. If an action is commenced within a year of a transaction which has the effect of giving a creditor a preference over others, the transaction is a fraudulent preference regardless of intent. ${ }^{6}$

Either a fraudulent conveyance or a fraudulent preference " is void as against the creditor or creditors injured, delayed, prejudiced or postponed.""

\section{B. THE BANKRUPTCY ACT ${ }^{8}$}

\section{Settlements}

The Bankruptcy Act does not deal with fraudulent conveyances as such. Instead it deals with certain voluntary conveyances called "settlements" and "reviewable transactions". A settlement is a disposition of property, either directly or through a trustee, for the benefit of the person on whose behalf the settlement is made but with the contemplation that the property in some form should be retained by the settlor. ${ }^{9}$ Thus, an outright gift is not a settlement unless some continued enjoyment by the settlor is secured.

By virtue of s-s. 69(1), where a settlor becomes bankrupt within a year of making the settlement the settlement is void as against a trustee in bankruptcy. By virtue of s-s. 69(2), where a settlor becomes bankrupt within five years of making the settlement the settlement is void provided the trustee can prove either that:

(1) the settlor was, at the time of making the settlement, unable to pay his debts without the aid of the property comprising the settlement; or

(2) the interest of the settlor in the property did not pass on the execution of the settlement.

The second proviso from s-s. 69(2) refers not to mere continued enjoyment but to actual retention of a part of the legal property interest, as

3. S-s. 1(a). For a discussion of the meaning of insolvency, see Canadian Imperial Bank of Commerce v. Grande Cache Motor Inn Ltd., supra n. 1 at 327.

4. S-s. 1(b).

5. S-s. 2(b). Some authority indicates that fraudulent intent must be proven on the parts of both the debtor and the creditor, although the language of the subsection would not appear to support the conclusion: Burton v. $R$ \& M Insurance Ltd. (1977) 5 Alta. L.R. (2d) 14 (S.C.); Re Barnett (1983) 43 A.R. 215 at 219 (Q.B.). In light of the Supreme Court of Canada's decision in Hudson v. Benallack, infra n. 15 (considering effectively similar language in s. 73 of the Bankruptcy Act), such decisions are doubtful. Although the bona fides of the creditor is relevant for the purposes of s. 6, discussed infra, s. 6 refers to requirements other than bona fides. In order to reflect the rationale outlined by the Supreme Court in Hudson v. Benallack and in order not to render s. 6 meaningless, lack of fraudulent intention on the part of the creditor should not alone be sufficient to prevent a finding that a transaction constitutes a fraudulent preference.

6. S. 3 combined with s-s. 4(2).

7. Ss. 1,2 and 3.

8. R.S.C. 1970 , c. B-3.

9. Traders Trust Co. v. Cohen [1927] 3 W.W.R. 473 (Man. K.B.); Re Barnett, supra n. 5. 
when the settlor settles property upon himself or retains power to revoke the trust. ${ }^{10}$

\section{2. "Reviewable Transaction"}

A "reviewable transaction" is a defined term and means generally a transaction between two people who do not deal with each other on an arm's length basis." A court may review such a transaction where one of the individuals becomes bankrupt within a year of the transaction. Where consideration is "conspicuously" inappropriate the court may order any person being privy to the transaction with the bankrupt to make up the shortfall. ${ }^{12}$ Fraudulent intent need not be proven.

\section{Fraudulent Preferences}

By virtue of s. 73 of the Bankruptcy Act, any conveyance or transfer made by an insolvent person in favour of a creditor with a view to giving the creditor a preference is fraudulent and void as against the trustee in bankruptcy, if the person making the gift becomes bankrupt within three months after the conveyance. Intention to give preference is inferred from effect of giving a preference ${ }^{13}$ and the period is extended to 12 months where the person preferred does not deal on an arm's-length basis with the person preferring. ${ }^{14}$ It is necessary to demonstrate fraudulent intention only on the part of the debtor. ${ }^{15}$

\section{THE STATUTE OF ELIZABETH ${ }^{16}$}

The Statute of Elizabeth, which has been held to be law in Alberta, ${ }^{17}$ addresses only the question of fraudulent conveyances. ${ }^{18}$ The Statute provides that grants, alienations, conveyances (et cetera) of lands or goods for the "Purpose and Intent, to delaye, hynder or defraude Creditors and others" shall be "utterly voyde frustrate and of none Effecte" against those creditors and others whose suits, debts (et cetera) "shall or mought be in any wyse dysturbed hyndered delayed or defrauded". 19

The language of the Act is broad and the courts have traditionally construed the terms liberally. ${ }^{20}$ Unlike the Fraudulent Preferences Act and the Bankruptcy Act, there is no insolvency requirement. ${ }^{21}$ Subject to

10. Re Baker [1936] Ch. 61 .

11. Ss. 3 and 4.

12. S-s. 78(2).

13. S-s. 73(2).

14. S. 74.

15. Hudson v. Benallack [1975] 6 W.W.R. 109 (S.C.C.).

16. (1571) 13 Eliz. c. 5.

17. Goyan v. Kinash [1945] 2 D.L.R. 749 (Alta. S.C.); Toronto-Dominion Bank v. Michael [1973] 1 W.W.R. 656 (Alta. C.A.).

18. See the discussion infra n. 46.

19. Supra n. 16.

20. Cadogan v. Kennett (1776) 98 E.R. 1171; Twyne's Case (1601) 76 E.R. 809.

21. Of course the issue of fraudulent conveyances does not arise unless, at some point, the debtor's assets become insufficient to meet the requirements of his creditors and insolvency will be relevant to determining fraudulent intent. 
qualifications to be discussed below, once it is shown that an actual disposition ${ }^{22}$ of property was executed with the intention to prejudice a creditor or creditors, and at least one creditor is adversely affected, the conveyance may be void.

\section{THE CRIMINAL CODE ${ }^{23}$}

Section 350 of the Criminal Code creates the indictable offence of disposing of property by "gift, conveyance, assignment, sale, transfer or delivery" with intent to defraud creditors. The section applies also to a person who receives property with intent that any one should defraud his creditors. Provided that intention is proven, it matters not whether a creditor is actually adversely affected. ${ }^{24}$ It should be noted also that one (such as a legal or financial advisor) who "does or omits to do anything for the purpose of aiding any person to commit" an offence is party to the offence. $^{25}$

\section{FRAUDULENT INTENTION}

\section{A. THE MEANING OF "INTENT TO DEFRAUD"}

Much of the case law on the meaning of intent to defraud relates to the Statute of Elizabeth but there is no reason to believe that the dicta in those cases would not apply to cases under the Fraudulent Preferences Act and even (with some reservations to be discussed below) to the Criminal Code, since both of those Acts require intention to defraud or at least to defeat creditors.

In Re Pearson the court discussed the meaning of "fraudulent" as follows: ${ }^{26}$

This deed is plainly fraudulent upon the face of it. What is the meaning of it? The settlor in effect says, "I have got $f 1,000$; I do not intend my creditors to have a farthing of it; and to accomplish that purpose I will settle it in such a way that, if by any accident my creditors should hereafter have a claim to it, it shall go to some one else." That is as plainly fraudulent as possible.

In $R e$ Lane-Fox, ${ }^{27}$ a settlement by a woman did, as it turned out, have the effect of prejudicing creditors. But, in contrast to the facts of Re Pearson, the purpose of the settlement was to put her substantial assets into the hands of trustees who could manage them better than she. The court held that this "honest" settlement should not be set aside..$^{28}$ Thus it appears that one harbours an intent to defraud creditors if he makes a settlement not for the purpose of enriching the donee, avoiding tax or any other legitimate or

22. The Alberta Court of Appeal has indicated in Sembaliuk v. Sembaliuk (1984) 35 Alta. L.R. (2d) 193 that, to be successfully challenged, a transaction must at least involve an actual disposition of property. A disclaimer of a gift under a will was held not to constitute a fraudulent conveyance.

23. R.S.C. 1970, c. C-34.

24. R. v. Crew [1926] 4 D.L.R. 841 (Ont. C.A.).

25. S. 21.

26. [1876] 3 Ch. 807 at 809 .

27. [1900] 2 Q.B. 508.

28. See also Havel v. Galemar Holdings Limited (1981) 42 C.B.R. (N.S.) 295 (Ont. S.C.); Royal Bank of Canada v. Thiessen (1981) 38 C.B.R. (2d) 284 (Man. Q.B.); Re Ross (1983) 46 C.B.R. (N.S.) 43 (N.S.S.C.). 
"honest" purpose, but for the primary purpose of removing property out of the reach of creditors. ${ }^{29}$

\section{B. PROVING FRAUDULENT INTENTION}

Intent to defraud creditors may normally be inferred from the circumstances surrounding the transaction. There may be a presumption that one who makes a conveyance at a time when he is insolvent or which renders him insolvent does so with a fraudulent intention. As well, hallmarks or "badges" of fraud exist. In addition to grossly inadequate consideration, these hallmarks include circumstances in which the debtor transfers essentially all his assets, retains possession of the property or transfers the property to a relative,,$^{30}$ although there is no authoritative list of the hallmarks and each case must be considered on the basis of its surrounding circumstances. ${ }^{31}$ Authority indicates that intention to defraud will normally be inferred from evidence demonstrating that the effect of a transfer is to defeat or delay creditors, ${ }^{32}$ although the debtor may be allowed to produce evidence of his honest purpose. ${ }^{33}$

\section{FRAUD UNDER THE CRIMINAL CODE}

Whereas the other fraudulent conveyances legislation refers to intent to delay or hinder creditors instead of or as well as intent actually to defraud, the Criminal Code applies only where there is "intent to defraud". The authorities tend to treat "intent to delay, hinder, prejudice" and the like as being synonymous with "intent to defraud" and Duncan and Honsberger wrote that, in the context of bankruptcy law, "fraudulent"' has a technical meaning and "does not necessarily include the idea of a common law fraud, or even of moral fraud". ${ }^{34}$ Although s. 350 may be expected generally to import the principles of fraudulent conveyances legislation, a higher standard is required to constitute the criminal offence than to warrant an order unwinding the transaction.

At the very least, the omission of such words as "prejudice" and "hinder" from s. 350, combined with the criminal standard of proof, would render inapplicable the jurisprudence, referred to earlier, whose language suggests presumed intention to defraud from the fact that a transaction renders the grantor insolvent and thereby prejudices the claims of creditors. The criminal court would have to be satisfied, on the basis of

29. In Burton v. $R \& M$ Insurance Ltd., supra n. 5, it is suggested that, for the purposes of the Fraudulent Preferences Act, the fraudulent intention must be the "predominant" intention of the debtor. See also Re Laventure (1985) 59 A.R. 28 (Alta. Q.B.).

30. Twyne's Case, supra n. 20. Examples of cases in which intent was inferred from the fact that the debtor denuded himself of essentially all of his assets occur in Sun Life Assurance Company of Canada v. Elliott (1900) 31 S.C.R. 91 and Bank of Montreal v. Crowell (1980) 34 C.B.R. (N.S.) 15 (N.S.S.C.). A case in which fraud was inferred from the close relationship between the parties is Bank of Nova Scotia v. Zgurski (1970) 72 W.W.R. 464 (Alta. S.C.).

31. Meeker Cedar Products Ltd. v. Edge (1968) 12 C.B.R. (N.S.) 49 (B.C.C.A.); affd. (1968) 12 C.B.R. (N.S.) 60 (S.C.C.).

32. Freeman v. Pope [1869-70] $5 \mathrm{Ch}$. App. 538; Sun Life Assurance Company of Canada v. Elliott, supra n. 30.

33. Mandryk v. Merko [1971] 2 W.W.R. 542 (Man. C.A.).

34. L. Duncan \& J. Honsberger, Bankruptcy in Canada (3rd. ed. 1961) 181. 
direct evidence, that the grantor entertained a primary and actual intention to remove assets from the reach of individuals who, to the knowledge of the grantor, had valid claims against those assets. ${ }^{35}$ Thus, instead of giving rise to any sort of legal presumption, surrounding circumstances constituting the usual "badges" of fraud would give rise, at most, to mere reasonable inferences about a grantor's intention. In the context of criminal prosecution, the accused would be acquitted if he could demonstrate, for example, that an "honest" ulterior objective might have existed.

\section{CONSIDERATION}

\section{A. CONSIDERATION AND PREJUDICE TO CREDITORS}

It may be thought that conveyances for good consideration could not prejudice the interests of any creditor (or other) since the debtor has simply exchanged transferred assets for other assets of value. However, there are a number of ways in which a debtor may prejudicially affect his creditors in the course of transferring property, for value, to an associate or to one of his creditors. For example, the consideration may be of a less liquid character than the debtor's original property, may be located in a foreign jurisdiction or, for other reasons, may be beyond the reach of the sheriff's bailiff.

Instead, a debtor may transfer assets to a creditor in exchange for his creditor's reliable promise to pay over time. If the creditor were allowed, in such circumstances, to exercise a right of set-off each time a payment were due to be paid by him, the creditor would avoid the rule requiring a pro rata distribution to creditors on insolvency of a debtor and thereby gain an unfair advantage over the other creditors. There is no doubt, therefore, that a transfer of assets for consideration may, at least in theory, be prejudicial to the interests of creditors and it is possible that a debtor might harbour the requisite intention to defraud while receiving valuable consideration for the transferred assets..$^{36}$ The practical task of proving that such intention did in fact exist will, of course, be very difficult in face of valuable consideration.

\section{B. STATUTORY PROVISIONS}

\section{Statute of Elizabeth}

Despite the fact that consideration does not preclude prejudice and fraud, the Statute of Elizabeth contains a provision which excepts from the proscriptive sweep of the Statute any transfer of assets made ${ }^{37}$

upon good Consyderation, and bona fide lawfully conveyed . . . to any [person] or [persons] or Bodyes Politique or Corporate, not having at the tyme of suche Conveyaunce ... any maner of Notice or Knowledge of suche Covyne Fraude or Collusion .... .

35. See R. v. Ehresman (1979) C.B.R. (N.S.) 209 at 210 and 212; affd. (1980) 121 D.L.R. (3d) 505 (B.C.C.A.).

36. See the dicta in Stewart v. Zacharuk [1949] I W.W.R. 213 (Sask. K.B.) at 219-20; Faulhaber v. Ulseth [1976] 4 W.W.R. 48 (Alta. S.C.) at 59-60; Burton v. $R \& M$ Insurance Ltd., supra $\mathrm{n}$. 5 at 18.

37. Supra n. 16. 
Consequently, in a case where good consideration has been given, to succeed under the Statute of Elizabeth the impugning creditor must show that the transferee had knowledge of the fraudulent intention of the transferor and, moreover, that there was an element of bad faith in the conduct of the transferee. ${ }^{38}$ Although good consideration is not, without more, a sufficient defence, the task of the challenging creditor in face of good consideration is onerous indeed. ${ }^{39}$

\section{The Bankruptcy Act}

Subsection 69(3) of the Bankruptcy Act provides that s. 69, respecting settlements, does not extend to, inter alia, a settlement made in favour of a purchaser or encumbrancer in good faith and for valuable consideration. Case law confirms that the saving provision is substantially identical to that in the Statute of Elizabeth..$^{40}$

\section{Fraudulent Preferences Act}

By the combined effect of ss. 2 and 3 of the Fraudulent Preferences Act, a creditor who alleges a preference, commences an action within a year of the impugned transaction and demonstrates the prejudicial effect of the transaction will succeed. This is so despite any evidence of good consideration and lack of knowledge and bad faith on the part of the preferred creditor.

Furthermore, even if the special provisions of ss. 2 and 3 cannot be invoked, the general exception provision of the Fraudulent Preferences Act is narrower in scope than its counterpart in the Statute of Elizabeth. Rather than requiring mere "good consideration", which may connote something less than fair value, ${ }^{41}$ the exception requires the defending debtor to demonstrate that the transferred property bears a "fair and reasonable relative value" to the consideration. ${ }^{42}$ Moreover, in addition to requiring good faith, the Act provides that the payment or transfer be in

38. Toronto-Dominion Bank v. Michael, supra n. 17; Re Surkan (1979) 32 C.B.R. (N.S.) 141 (Alta. Q.B.); Re Laventure, supra n. 29; cf. Solomon v. Solomon (1977) 79 D.L.R. (3d) 264 (Ont. H.C.) considering a similar provision under Ontario's Fraudulent Conveyances Act (R.S.O. 1970, c. 182 now R.S.O. 1980, c. 176).

39. In Mulcahy v. Archibald (1898) 28 S.C.R. 523 at 529, the Supreme Court of Canada held that in face of valuable consideration, even though the transferee was aware of the fraudulent intention, the transfer will not be impeached unless the transferee were to "directly or indirectly make himself an instrument for the purpose of subsequently benefiting the transferor . . .". In Meeker Cedar Products Limited v. Edge, supra n. 31, the court, considering a statutory provision nearly identical to the exception contained in the Statute of Elizabeth, held that the transferee must be shown to have shared the fraudulent intention of the transferor.

40. See Re Barnett, supra n. S. Although some authority indicates that knowledge on the part of the transferee may be suffucient to undermine his good faith (Re Klem (1959) 38 C.B.R. 52 at 56; $\operatorname{Re}$ Woods (1979) 29 C.B.R. (N.S.) 210 (Ont. S.C.)), it is impossible to reconcile such cases with those cited supra $\mathrm{n}$. 39 . Surely "bona fide" means precisely the same thing as "good faith". See also Solomon v. Solomon, supra n. 38.

41. Leighton v. Muir (1962) 34 D.L.R. (2d) 332 (N.S.S.C.). However, love and affection is not "good consideration" for the purposes of the Statute of Elizabeth: Bank of Montreal v. Crowel (1980) 34 C.B.R. (N.S.) 15. See also the cases cited infra n. 45.

42. For a discussion of the meaning of "fair and reasonable value", which need not be the same as "market value", see Westinghouse Canada Ltd. v. Caldwell (1979) 31 C.B.R. (N.S.) 276 (B.C.S.C.). 
consideration for a present sale or delivery of goods, property or money or must constitute security for a present advance of money. ${ }^{43}$ Thus, consideration by way of, for example, the transferee's promise to pay over time or by way of some form of past consideration should not constitute sufficient consideration for the purposes of s. 6 of the Fraudulent Preferences Act. ${ }^{44}$ Such consideration may well be sufficient for the purposes of invoking the exception provision under the Statute of Elizabeth, a statute otherwise broader in its proscriptive scope than the Fraudulent Preferences Act. ${ }^{45}$

\section{THE MEANING OF “CREDITORS” AND “CREDITORS OR OTHERS"}

\section{A. SCOPE OF THE TERM "DEBT"}

In his book on creditor-debtor law, Professor Dunlop discusses definitions of debt ${ }^{46} \mathrm{He}$ suggests that the term is not a precisely defined term of art and that the meaning varies with the context. But the most common use of the word "debt", writes Dunlop, is "to describe an obligation to pay a sum certain or a sum readily reducible to a certainty". ${ }^{47}$

On the basis of the general definition of debt offered by Dunlop, one would exclude, from the concept of debt, contingent or unliquidated claims and claims which would not accrue until some time in the future, especially where the claimants were as yet unidentified. Therefore individuals who would or might benefit from contingent, unliquidated or future claims could not be within the class of current creditors of the debtor. However, it appears from the case law that the reference to "others" in legislation such as the Statute of Elizabeth has broadened the scope of

43. A special case appears to be a payment of money to a creditor, which may fall within the scope of the exception of s. 6 regardless of the bona fides of the payment or receipt of present consideration (Re Pontiac Forest Products Ltd. (1982) 44 C.B.R. (N.S.) 251 (Ont. S.C.); Canadian Credit Men's Trust Association v. Spivak [1927] 1 D.L.R. 577 (Alta. C.A.)). The courts which have rendered decisions in support of the exception have construed the words "any payment of money to a creditor" in isolation (without reference to the qualifications of bona fides or consideration). Some of the cases may be distinguishable for the purpose of our modern s. 6 whose format clearly indicates that at least the "fair and reasonable relative value" requirement refers back even to a payment of money to a creditor. (But see Jack Cewe Ltd. v. Irving (1978) 26 C.B.R. (N.S.) 142 (B.C.S.C.) considering a format similar to that of s. 6 and suggesting that any payment on account of a debt to a creditor must be in consideration for fair and reasonable value). In any event, that a payment of money to a creditor should, without more, be exceptional is ludicrous and defeats the purpose of provisions (contained in all of the modern legislation) which create a legitimate exception in special cases involving payment of money to a creditor (see our s-s. 9(a)).

44. However, Jack Cewe Ltd. v. Irving, supra n. 43, indicates that forbearance to sue may constitute sufficient consideration for the purposes of a statute like the Fraudulent Preferences Act. It should be restated that, even if the standard of s. 6 is not met, consideration may nevertheless be a factor relevant to determining whether fraudulent intention existed.

45. Glegg v. Bromley [1912] 3 K.B. 474 (creditor permitted to accept additional security in exchange for implied agreement to extend terms of repayment); Mulcahy v. Archibald, supra n. 39; Toronto Dominion Bank v. Melanson (1981) 39 C.B.R. (N.S.) 293 (N.B.Q.B.); $R e$ Garrett (1979) 30 C.B.R. (N.S.) 150 (Ont. S.C.); Anderson Lumber Company v. Canadian Conifer Ltd., supra n. 1 (creditor permitted to accept security for pre-existing debt). Consequent to cases such as these, the Statute of Elizabeth is of no utility to a party who wishes to attack a fraudulent preference as opposed to a fraudulent conveyance.

46. C.R.B. Dunlop, Creditor - Debtor Law in Canada (1981) 15-20.

47. Id. at 19-20. 
fraudulent conveyances legislation to such an extent that those with contingent, unliquidated or future claims have been able to challenge successfully prejudicial conveyances of property. Even legislation which makes reference only to "creditors" has sometimes been used successfully against a class of individuals broader than that suggested by the description "current debtors of the creditor".

\section{B. SUBSEQUENT CREDITORS}

A creditor whose debt arises subsequent to the date upon which his debtor is alleged to have made a conveyance (a "subsequent creditor") faces the argument that he does not fall within the scope of "creditors" or "creditors or others" as those terms are used in the applicable legislation. In Halsbury's Laws of England it is stated broadly that "subsequent creditors have the same right to set aside a conveyance made with intent to defraud them as creditors whose debts were due at the date of conveyance" ${ }^{48}$ The only difference between the ability of a subsequent creditor to set aside a conveyance and that of a current creditor, it appears, is that it is much more difficult for the subsequent creditor to prove fraudulent intent. However, it must be noted that the jurisprudence discussed in the following paragraphs occurs under the Statute of Elizabeth and some cases under legislation referring only to "creditors" rather than to "creditors and others" suggest that future creditors might not have standing. ${ }^{49}$

It has been held that a subsequent creditor must prove either that the settlor made the conveyance with the express intent to delay, hinder or defraud or (and this is required effectively by the Fraudulent Preferences Act in all cases) that by the conveyance the debtor was reduced to insolvency..$^{30}$ Even if the conveyance does reduce a debtor to a state of insolvency, where all creditors existing at the time of the conveyance have subsequently been paid off it will be very difficult for a future creditor to prove fraudulent intent. ${ }^{51}$ Thus, unlike the case of the concurrent creditor, the subsequent creditor may not raise a presumption of fraud on the basis that a previous conveyance adversely affects his claim; he must show positive evidence that the conveyance was effected for the purpose of avoiding creditors. ${ }^{32}$ If the requirements were otherwise, any conveyance made during the life of a debtor would be voidable upon his becoming insolvent.

It is not necessary that the settlor have particular creditors in mind at the time of the conveyance. One who makes a conveyance while solvent but shortly before entering a hazardous business may be taken to have contemplated future creditors and to have intended to protect property from their claims. ${ }^{33}$

48. 18 Halsbury's Laws (4th) para. 377.

49. Traders Group Ltd. v. Mason (1973) 43 D.L.R. (3d) 76 (N.S.S.C.).

50. Spirett v. Willows (1865) 46 E.R. 649; Cromwell v. Comeau (1957) 8 D.L.R. (2d) 676 (N.S.S.C.).

51. Jenkyn v. Vaughan (1856) 3 Drewry 419,61 E.R. 963; Gauthier v. Woollatt [1940] 1 D.L.R. 275 (Ont. S.C.).

52. Re Lane Fox, supra n. 27.

53. Mackay v. Douglas (1867) 14 Equ. 106. 


\section{UNLIQUIDATED CLAIMS AND CONTINGENT CLAIMS}

\section{Unliquidated and Contingent Claims as "Future" Claims}

It follows from what has been said about subsequent creditors that, at least under the Statute of Elizabeth, ${ }^{54}$ individuals with contingent claims and claims for unliquidated damages must be "creditors" for the purposes of fraudulent conveyances legislation. A conveyance with intent to remove property from within the reach of a claimant who may have a claim in the future, or whose claim has not been quantified, is a conveyance to defeat future creditors. Provided it does eventually accrue, the fact that a claim is not bound to accrue should not defeat the claimant's right. Where the claim is remote, it will simply be more difficult for a creditor to show that the conveyance was made for the purpose of defeating the claim. However, as will be shown, courts have not consistently applied the subsequent creditor analogy to these sorts of claims.

\section{Unliquidated and Unproven Claims}

One who has a claim for mere unliquidated damages either in tort or contract is qualified to apply to have a conveyance set aside, under legislation which, like the Statute of Elizabeth, applies to transactions fraudulent against "creditors and others".. ss In contrast, the Fraudulent Preferences Act of Alberta and the Criminal Code, under which only transactions affecting "creditors" are reversible and offensive, probably will not assist one who has only an unliquidated claim. ${ }^{56}$

Under both kinds of legislation, it appears that the applicant must prove that he had a valid, even if unliquidated, claim at the time of the impugned transaction. The existence of the creditor's claim at the time of the transaction might reasonably be considered a factor determining whether fraudulent intention exists and could be treated simply as an issue of evidence, just as is the question whether a creditor's claim is liquidated. However, the Court in Bell v. Williamson ${ }^{37}$ treated the validity of the creditor's claim as an issue of standing, rather than of evidence, and dismissed the application on that basis.

The Bell v. Williamson case was decided under the Fraudulent Conveyances Act of Ontario. Since that Act, like the Statute of Elizabeth, grants remedies to "creditors and others" it is difficult to reconcile it with those cases considering the status of the subsequent creditor under the Statute of Elizabeth and discussed above. The case is also difficult to reconcile with cases on the position of the guarantor to be discussed below. However, it should be noted that in Bell v. Williamson not only did the conveyance occur before the creditor's claim was proven but so did the creditor's

54. And other legislation, such as Ontario's Fraudulent Conveyances Act, supra n. 38, which makes reference to prejudice to both "creditors and others".

55. City of Toronto v. McIntosh (1977) 16 O.R. (2d) 257 (Ont. H.C.); Bell v. Williamson [1946] 1 D.L.R. 372 (Ont. C.A.); Murdoch v. Murdoch (1976) 1 Alta. L.R. 135 (S.C.); Faulhaber v. Ulseth, supra n. 36 at 54.

56. Don's World Travel Service Ltd. v. Vernon, unreported, 10 April 1985, J.D. of Calgary, No. 8301-09509 (Alta. Q.B.); Faulhaber v. Ulseth, supra n. 36.

57. Supra n. 55 at 375. 
application to set aside the conveyance. It is clear from the judgment that the court was concerned about the anomaly which would occur if, having succeeded in his application to have the conveyance set aside, the creditor then failed, in a subsequent action against the alleged debtor, to prove his claim. Perhaps the Bell v. Williamson case should be construed to stand for the reasonable proposition that an applicant must adduce evidence to prove that at the time of the application, though not necessarily at the time of the alleged conveyance, he has a valid claim against the respondent and therefore has standing.

\section{The Position of the Guarantor}

A type of contingent debt is the obligation of a guarantor of a debt. It is well established that the liability of a guarantor does not arise until the principal debtor has made default. ${ }^{58}$ Arguably, the creditors of the principal debtor are not creditors of the guarantor until the act of default on the part of the principal debtor. But there is authority to suggest that the fraudulent conveyances legislation purporting to benefit both "creditors and others" will void a settlement of the property made by one who is liable on a guarantee, at least where the risk of being called upon to pay on the guarantee is "serious and substantial".

In Riddler v. Riddler ${ }^{39}$ the defendant guaranteed his son's bank account for payment of the balance up to $£ 61,000$ which should be from time to time owing. At the time the guarantee was made, $£ 6,700$ was owing. When the balance reached $£ 61,512$, the defendant transferred a leasehold interest, worth about $£ 6,210$ annually, to another son in trust. Unable to satisfy its debt through the son who had gone bankrupt, the bank later sued the defendant and sought to have the settlement set aside. The Chief Clerk upheld the settlement on two grounds, one of which was that "the Bank were not creditors in the strict sense of the term at the date of the deed." On appeal, the court allowed that "there might be a state of things in which the liability of the guarantor might be so remote that it might not be regarded", but here the son did not have enough assets "to prevent the father's liability under the guarantee from being a serious and substantial one at the time the settlement was executed". Accordingly, the settlement was held to contravene the statute.

The Riddler case has been adopted in Canada for the purposes of the Statute of Elizabeth. ${ }^{60} \mathrm{~A}$ similar approach was taken in Re Skinner ${ }^{61}$ a case decided under the Fraudulent Preferences Act of British Columbia ${ }^{62}$ and in Bank of Nova Scotia v. Holland ${ }^{63}$ a case decided under the Fraudulent Conveyances Act of Ontario. ${ }^{64}$ Since at the time of the conveyance in each

58. 20 Halsbury's Laws (4th) para. 158.

59. (1882) 22 Ch. Div. 74.

60. Toronto Carpet Co. v. Wright (1912) 3 D.L.R. 725 (Man. K.B.). See also Traders Group Ltd. v. Mason, supra n. 49.

61. (1960) 27 D.L.R. (2d) 74 (B.C.S.C.).

62. R.S.B.C. 1960, c. 156 (referring to "creditors and others") now Fraudulent Preference Act, R.S.B.C. 1979, c. 143. See also Bank of Montreal v. Kelliher (1980) 36 C.B.R. (N.S.) 205 (B.C.S.C.).

63. (1979) 32 C.B.R. (N.S.) 153 (Ont. S.C.).

64. Supra n. 38. 
of these cases the guarantor had not become liable on the guarantee, the results of the cases are inconsistent with Bell v. Williamson, discussed above, in which a creditor was said to have standing only if he had a valid claim against the transferor at the time of the transfer.

Further supporting the conclusion that a creditor of a principal debtor is a creditor of the guarantor, even before default of the principal debtor, is a case deciding an issue under the Bankruptcy Act. The Bankruptcy Act provision does not focus on the effect of a settlement upon creditors, in order to determine legality of the settlement, and most of what is said in this part therefore has no direct bearing on that Act. However, as indicated above, in certain circumstances the trustee in bankruptcy must show that the bankrupt was unable to pay his debts without the aid of the assets comprised in the settlement. In Re Shickele, ${ }^{65}$ it was held that "debts" includes a contingent liability on a guarantee, even though the principal debtor was not in default at the time of the transfer and no demand had been made on the guarantor. The operation of the fraudulent conveyances provision under the Bankruptcy Act is different from that of other fraudulent conveyances legislation. Nevertheless, the effect of the $R e$ Schickele decision is, like that of Riddler and the cases following Riddler, to prevent a guarantor from making a conveyance for the purpose of removing property from within the reach of a creditor of the principal debtor in anticipation of default on the part of the principal debtor.

Both Re Skinner and Re Shickele were decided under legislation which does not purport to benefit persons other than "creditors"; that is, there is no reference to "others". Those cases would therefore support an argument that the contingent or subsequent creditor, such as the beneficiary of a guarantee prior to default of the principal debtor, would have standing under the Fraudulent Preferences Act (Alberta). However, the issue is unresolved. In Westinghouse Canada Ltd. v. Caldwell ${ }^{66}$ the British Columbia Supreme Court (without reference to Re Skinner which considered the same statute) held that the beneficiary of a guarantee prior to default of the debtor was not a "creditor" within the meaning of the Fraudulent Preferences Act of British Columbia, ${ }^{67}$ a statute which omits reference to "others". The omission was apparently an operative factor since the court also considered the applicability of the Fraudulent Conveyances Act of British Columbia, ${ }^{68}$ a statute which does refer to "creditors and others", without drawing the same conclusion about the status of the beneficiary of the guarantee.

It is suggested above that, vis-a-vis a guarantor, a creditor of the principal debtor is conceptually simply a species of "subsequent creditor". Therefore it should not be surprising that most cases dealing with the ability of subsequent creditors to set aside transactions are consistent with cases growing out of the Riddler case. The court in Riddler focused on whether the guarantor's liability was a "serious and substantial one". If the risk of being called upon to pay out on the guarantee were remote, then

65. (1977) 25 C.B.R. (N.S.) 67 (B.C.S.C.).

66. Supra n. 42.

67. Supra n. 62.

68. R.S.B.C. 1960 , c. 155 now Fraudulent Conveyance Act, R.S.B.C. 1979, c. 142. 
it would be difficult to prove that the conveyance was motivated by a fraudulent desire to avoid the creditor's claim. Thus the test of whether a guarantor may make a conveyance is generally similar in effect to the test applied under the Statute of Elizabeth to any conveyance which may prejudice a subsequent creditor. In each case the settlement is illegal if the evidence shows that the transaction is motivated by a desire to avoid a claim which the transferor knows is likely to arise at some time in the future. There is some authority to suggest a different result might prevail under legislation purporting to benefit "creditors" only.

\section{4. "Creditor" Under the Criminal Code}

In the context of a criminal case under s. 350 and the strict standard of proof imposed upon a prosecutor, ${ }^{69}$ arguably the definition of "creditor" in $s .350$ should be strictly construed, especially since $s .350$ is among the statutes which make no reference to "others" who might be affected by a conveyance.

The cases outlined above on the subject of the rights of subsequent creditors may apply to the case to be decided under the Fraudulent Preferences Act, as well as to those under the Statute of Elizabeth. But they should not apply to the Criminal Code whose purposes are quite different from those of the Fraudulent Preferences Act, the Bankruptcy Act and the Statute of Elizabeth. Although some courts have been willing to unwind settlements intended to affect adversely subsequent creditors under those Acts, courts may be more hesitant in a criminal prosecution to construe "creditors" to include "subsequent creditors" and "contingent creditors". Where the claim of the creditor is not established as of the date of the conveyance, surely the restrictive view of "creditor" from the Bell and City of Toronto cases is appropriate. And to hold that a guarantor is a "creditor" upon signing the guarantee is, as indicated, inconsistent with the principle that a guarantor's liability is contingent upon the default of the principal debtor. Therefore, at least for the purposes of s. 350, arguably the strict construction should prevail.

\section{CONCLUSIONS}

When advising a client regarding the legality of a proposed transfer of assets, a solicitor or financial advisor must be aware of the provisions of fraudulent conveyances legislation. Since the Statute of Elizabeth is still in force, at least in Alberta, it matters not whether the client is on the eve of insolvency at the time of the conveyance. Neither will the provisions of the Statute of Elizabeth and, possibly, even of the Fraudulent Preferences Act and the Criminal Code necessarily be avoided by the fact that persons prejudiced are not technically "creditors" at the time of the conveyance. All that such a person need show is that the purpose of the transaction was fraudulent in the sense that it was executed for the purpose of avoiding the claimant's claim, whether liquidated or not, and, according to most of the cases, whether vested or not. The fact that a claimant was not technically a creditor at the time of the conveyance may not affect his right, but only his ability to prove the fraudulent intent of the transferor.

69. See the discussion in R. v. Goulis (1981) 37 C.B.R. (N.S.) 290 at 293ff. (Ont. C.A.). 
Where the client has made an assignment or has been the subject of a petition pursuant to the Bankruptcy Act, the risk of attracting the sanctions of the fraudulent conveyance legislation becomes more serious. In such circumstances a creditor (or the trustee) may proceed under either the Fraudulent Preferences Act or the Statute of Elizabeth. In addition, the provisions of the Bankruptcy Act may be triggered. Since the Bankruptcy Act generally avoids the questions of defining creditor and determining fraudulent intent, a transferor who becomes bankrupt, even several years after the conveyance, may find a conveyance that is a "settlement" can be unwound even though no intention to avoid the creditor was entertained.

An advisor should also be aware that a conveyance made with fraudulent intent may attract criminal sanctions, although a case in support of a criminal prosecution will be more difficult to make out than an application seeking an order to unwind the transaction. As well, the recipient of the conveyed property may be guilty of a criminal of fence and the legal advisor may well be a party.

A solicitor is well-advised to warn a client against executing any transaction whose purpose is to protect property from individuals who are or may become creditors of the client. ${ }^{70}$

70. For further discussion of some of the matters addressed in this paper, the following material may be referred: J.B. Laskin, et al., Debtor and Creditor: Cases, Notes and Materials (2nd ed. 1982) chap. 13; Legal Education Society of Alberta, Fraud, Fraudulent Conveyances and Fraudulent Preferences (1985); John T. Prowse, "Impeachable Transactions" in Legal Education Society of Alberta, Creditor-Debtor Law: A Refresher (1983); C.R.B. Dunlop, Creditor-Debtor Law in Canada (1981) chap. 15. 